\title{
Analisis Prestasi Belajar Mahasiswa Ditinjau dari Jurusan SMA, Jenis Kelamin, Jalur Masuk, dan Asal Daerah serta Implikasinya terhadap Kebijakan Penerimaan Mahasiswa Baru
}

\author{
Fara Himmah ${ }^{\text {a* }}$ \\ ${ }^{a}$ Universitas Brawijaya, Jawa Timur, Indonesia
}

\section{INFORMASI ARTIKEL}

\section{Article history:}

Dikirim tanggal: 08 Maret 2021

Revisi pertama tanggal: 26 Maret 2021

Diterima tanggal: 39 Maret 2021

Tersedia online tanggal: 14 April 2021

Keywords: performance of students, learning achievement, gender, high school major, student admission

\begin{abstract}
Academic performance of students, is an important thing in higher education institutions. The purpose of this study is to obtain empirical information that can be used to analyze differences in learning achievement between students from the path of entering high school majors, gender and regional origin and determine future student recruitment policies. Quantitative is methods of this research . using hypothesis a sample T-Test for comparing two different samples in pairs. The results in this study are There are significant and simultaneous influences of high school entrance and majors on student performance, There is a significant influence on high school majors on student achievement, There is a significant of gender on student IPK and there is no significant result from the region on student achievement.
\end{abstract}

\section{INTISARI}

Performa akademik dari mahasiswa dan mahasiswi, merupakan hal penting pada institusi pendidikan tinggi. Tujuan dalam penelitian ini adalah untuk memperoleh informasi empiris yang dapat digunakan untuk mengetahui perbedaan prestasi belajar antara mahasiswa dari jurusan SMA, jenis kelamin, jalur masuk, dan asal daerah, dan menentukan kebijakan rekrutmen mahasiswa dimasa mendatang. Penelitian ini menggunakan metode kuantitatif dengan pengujian hipotesis menggunakan sampel T-Test dan dengan uji beda dua sampel berpasangan. Penelitian ini memperoleh hasil bahwa terdapat pengaruh yang signifikan dan simultan jalur masuk dan jurusan SMA terhadap prestasi yang diraih mahasiswa, terdapat pengaruh yang signifikan dan simultan antara jurusan SMA,jenis kelamin dan jalur masuk terhadap prestasi mahasiswa, namun tidak terdapat pengaruh yang signifikan asal daerah terhadap prestasi belajar mahasiswa

2021 FIA UB. All rights reserved.

\section{Pendahuluan}

Perubahan tingkah laku diantaranya aspek pengetahuan atau kognitif, sikap atau afektif, maupun aspek psikomotorik merupakan salah satu yang diharapkan dari proses belajar. Salah satu perubahan aspek pengetahuan mahasiswa dapat dilihat dari indeks prestasi kumulatif (IPK) mahasiswa. IPK merupakan tolak ukur penguasaan akademik mahasiswa. Semakin baik penguasaan dalam bidang akademik mahasiswa, maka IPK yang diperoleh akan semakin tinggi pula.

Universitas Brawijaya sebagai salah satu Perguruan Tinggi Negeri di Indonesia yang paling diminati pada Tahun 2019. Hal ini karena banyaknya fakultas yang 
dimiliki serta suasana daerahnya yang nyaman. Banyaknya jumlah mahasiswa pada Universitas Brawijaya, tentunya memberikan keberagaman latar belakang mahasiswa baik dari asal daerahnya, jalur seleksi masuknya, jenis kelamin, dan jurusan pada saat sekolah menengah. Diantara banyaknya fakultas, terdapat beberapa fakultas pada Universitas Brawijaya yang memiliki daya tampung dalam jumlah besar. Menurut data yang diperoleh dari Bagian Akademik Universitas Brawijaya melalui aplikasi simpel.ub.ac.id, Fakultas Ilmu Administrasi, Fakultas Ekonomi dan Bisnis serta Fakultas Ilmu Sosial dan Ilmu Politik, merupakan tiga Fakultas Sosial dan Humaniora (Soshum) yang memiliki daya tampung terbanyak. Sebagai contoh, pada Tahun 2014, Fakultas Ilmu Administrasi memiliki daya tampung untuk mahasiswa baru sejumlah 1.170 orang, sedangkan Fakultas Ekonomi dan Bisnis memiliki daya tampung sebanyak 850 dan Fakultas Ilmu Sosial dan Ilmu Politik dengan daya tampung sebanyak 1.304. Ketiga fakultas tersebut menduduki tiga peringkat teratas daya tampung Universitas Brawijaya untuk Jurusan Soshum. Dengan jumlah mahasiswa yang besar, ketiga fakultas tersebut memenuhi persyaratan untuk dapat menjadi objek pada penelitian. Hasil dari penelitian ini diharapkan dapat dijadikan salah satu acuan untuk merumuskan kebijakan baru ataupun alternatif kebijakan pada Universitas Brawijaya yang lebih nyata karena objek yang diteliti adalah mahasiswa dari Universitas Brawijaya.

Perbedaan jenis kelamin berpengaruh terhadap pretasi akademik juga mendapatkan hasil yang sama dengan penelitian yang dilakukan oleh Nuryoto (1998) yang memperoleh hasil penelitian, yaitu prestasi akademik perempuann lebih baik dibandingkan dengan laki-laki secara umum. Karakteristik lainnya dari mahasiswa yang dapat mempengaruhi prestasi belajar mahasiswa yaitu latar belakang sekolah. Dalam penelitian sebelumnya, yaitu penelitian oleh Garkaz, Bahman \& Hadis (2011) yang sejalan dengan penelitian oleh Koh \& Koh (1999), Yilmaz Guney (2009); mengemukakan bahwa ada hubungan positif yang signifikan antara siswa dengan latar belakang bidang pada tingkatan sekolah sebelumnya, yaitu Sekolah Menengah Atas (SMA). Sejalan pula dengan penelitian Welsh, Anderson, \& Harris (1982) dalam Faridah (2003) yang menemukan bahwa perbedaan prestasi matematika secara substansial akan menjelaskan perbedaan pengalaman dalam matematika karena dalam kenyataannya, siswa yang sering berlatih soal-soal matematika memiliki kemampuan yang lebih baik dalam bidang matematika. Penelitian ini juga dikembangkan berdasarkan penelitian oleh Qudratullah (2014) yang mendapatkan hasil penelitian, yaitu (a) jalur seleksi mahasiswa berpengaruh terhadap prestasi mahasiswa tersebut, dimana prestasi mahasiswa yang diterima pada suatu perguruan tinggi melalui jalur eksternal, akan memperoleh nilai IPK lebih tinggi daripada mahasiswa yang diterima melalui jalur internal, (b) begitu pula dengan asal sekolah, berpengaruh terhadap prestasi mahasiswa, dimana mahasiswa yang berasal dari SMU/ SMK akan lebih baik prestasi belajarnya dibandingkan dengan mahasiswa dari asal sekolah MA, dan (c) hasil ketiga, yaitu ternyata tidak terdapat interaksi antara kedua faktor tersebut dalam mempengaruhi prestasi mahasiswa.

Dengan mengetahui perbedaan prestasi belajar mahasiswa melalui berbagai aspek, maka akan dapat menjadi acuan bagi Universitas Brawijaya dalam menentukan prosentase penerimaan mahasiswa baru dari masing-masing jalur masuk disetiap tahunnya. Terlebih lagi khususnya pada Program Studi Sosial Humaniora. Universitas Brawijaya diharapkan dapat memiliki pertimbangan dalam menentukan penambahan atau pengurangan kuota penerimaan mahasiswa baru dari jalur masuk SBMPTN, SNMPTN ataupun mandiri untuk fakultas dengan Program Studi Sosial Humaniora. Sehingga diharapkan prestasi belajar yang tinggi dapat diperoleh sebagian besar mahasiswa Universitas Brawijaya, khususnya yang berasal dari fakultas dengan Program Studi Sosial Humaniora.

Merujuk pada hal latar belakang diatas, rumusan masalah penelitian ini adalah adakah perbedaan prestasi belajar mahasiswa ditinjau dari jurusan SMA, jalur masuk, jenis kelamin dan asal daerah serta apa implikasi terhadap kebijakan rekrutmen mahasiswa dimasa mendatang?. Adapun tujuan penelitian adalah untuk memperoleh informasi empiris yang dapat digunakan untuk mengetahui dan mendapatkan hasil penelitian berupa perbedaan prestasi belajar antara mahasiswa dari jalur masuk, jurusan SMA, jenis kelamin, dan asal daerah. Serta untuk memperoleh informasi empiris yang dapat digunakan untuk menentukan kebijakan rekrutmen mahasiswa dimasa mendatang.

\section{Teori}

\subsection{Belajar}

Belajar merupakan suatu hal yang tidak dapat ditinggalkan dalam perjalanan hidup manusia. Belajar adalah suatu proses dimana seseorang melakukan suatu kegiatan yang berulang-ulang dengan tujuan untuk memperoleh suatu pemahaman atas suatu hal. Kegiatan belajar dapat dilakukan dimanapun, dilingkungan keluarga, dilingkungan pendidikan, baik secara sengaja, maupun tidak disengaja, dan dalam kesempatan yang direncanakan ataupun tidak. Belajar adalah bagian yang sangat penting dalam kehidupan manusia sebagai makhluk sosial dan budaya, yang mencakup segala sesuatu yang dipikirkan dan dikerjakan oleh manusia tersebut. Belajar merupakan tindakan yang memegang peranan penting dalam perkembangan kepribadian, 
kebiasaan, sikap, keyakinan, tujuan, dan persepsi manusia (Setiyoningsih, 2007).

\subsection{Prestasi Belajar}

Winkel (1989), dalam bukunya menjelaskan bahwa prestasi belajar adalah hasil suatu penilaian dibidang pengetahuan, keterampilan, dan sikap sebagai hasil dari proses belajar yang dinyatakan dalam bentuk nilai. Hampir sejalan dengan yang dikemukakan oleh Nurkholis (2007) yang menyebutkan bahwa, prestasi belajar adalah penguasaan terhadap suatu pengetahuan atau keterampilan yang dikembangkan oleh mata pelajaran, yang secara umum ditunjukkan dengan nilai dari suatu tes yang diberikan, berupa angka yang diberikan oleh guru. Sedangkan menurut Rusyan (1994) (dalam Nurkholis, 2007), menyebutkan bahwa prestasi belajar merupakan hasil dari suatu kegiatan atau pelaksanaan terhadap proses belajar. Untuk mencapai hal tersebut, maka dari itu diperlukan informasi-informasi yang mendukung, disertai dengan data-data yang bersifat objektif dan memadai.

Menurut Arifin (1990), prestasi berasal dari Bahasa Belanda yang berarti hasil usaha. Sedangkan Winkel (1987) pun menyebutkan bahwa prestasi belajar berarti adalah hasil yang bisa diberikan oleh mahasiswa. Lebih lanjut Winkel menjelaskan bahwa diperlukan adanya penilaian, evaluasi atau peninjauan terhadap hasil yang diperoleh mahasiswa setelah mengikuti proses belajar mengajar. Peninjauan juga selayaknya dilakukan terhadap komponen-komponen yang membentuk proses belajar mengajar.

\subsection{Jalur Seleksi Masuk Perguruan Tinggi}

Setelah lulus dari sekolah menengah atas, sebagian besar para lulusan tersebut akan melanjutkan pada jenjang yang lebih tinggi yaitu universitas. Para lulusan SMA berlomba-lomba untuk memperebutkan kursi kejurusan pada univesitas yang diinginkan yang terkadang satu kursi bisa diperebutkan oleh beberapa orang. Untuk melanjutkan pendidikan ke jenjang yang lebih tinggi, yaitu perguruan tinggi, yang bertujuan untuk membentuk sikap intelektual serta menyiapkan tenagatenaga terampil, mandiri dan profesional ini, para lulusan SMA harus mengikuti tes masuk perguruan tinggi yang dilaksanakan secara serentak ditingkat nasional.

\subsection{Jurusan di Sekolah Menengah Atas}

Sekolah Menengah Atas (SMA) merupakan jenjang pendidikan dimana siswa mulai mempelajari suatu hal secara lebih spesifik dan terpusat. Saat peserta didik pada Tahun Pelajaran 2006/ 2007 memasuki tahun ketiga dalam pendidikannya di SMA, peserta didik dihadapkan pada dua pilihan jenjang pendidikan, yaitu Ilmu Pengetahuan Alam (IPA) atau natural science dan Ilmu Pengetahuan Sosial (IPS) atau social science. Terkadang ada pula sekolah yang juga menyediakan pilihan jurusan selain IPA dan IPS, yaitu jurusan bahasa.

Pilihan ini harus dipikirkan secara tepat dan matang, pasalnya pilihan ini nantinya akan mempengaruhi masa depan peserta didik, terkait dengan pilihan jurusan yang hendak dipilih saat memasuki perguruan tinggi. Jurusan yang dipilih semasa SMA, merupakan bekal bagi peserta didik pada jenjang universitas nantinya, jika peserta didik memutuskan untuk melanjutkan studinya.

\subsection{Jenis Kelamin}

Penggolongan gramatikal terhadap kata benda yang secara garis besar berhubungan dengan dua jenis kelamin serta ketiadaan jenis kelamin atau kenetralan adalah deskripsi tentang gender menurut Ika (2010). Jenis kelamin manusia terdiri dari dua, yaitu pria dan wanita. Dalam hal intelegensi, tidak terdapat perbedaan yang mendasar antara pria dan wanita. Banyak pula penelitian yang membuktikan tidak adanya perbedaan yang signifikan antara intelegensi pria dengan intelegensi wanita, seperti yang disampaikan Dalyono dalam bukunya yang berjudul Psikologi Pendidikan. Wanita pada dasarnya memiliki kelebihan dalam hal mengerjakan soal-soal yang menyangkut penggunaan bahasa, hafalan, reaksi estetika, serta yang berhubungan dengan masalah sosial. Sementara dilain pihak, laki-laki cenderung memiliki kelebihan dalam hal penalaran abstrak, penguasaan matematika, dan mekanika atau structural skills (Dalyono, 2005, h. 192).

\subsection{Asal Daerah}

Menurut Hakim (2000) dalam Setiyoningsih (2007), kondisi lingkungan sekolah berpengaruh terhadap kondisi belajar. Oleh karena itu, diharapkan adanya guru yang baik dalam jumlah yang cukup memadai sesuai dengan jumlah bidang studi yang ditentukan. Selain itu, peralatan belajar yang cukup lengkap juga penting untuk dimiliki. Serta keberadaan gedung sekolah yang memenuhi persyaratan bagi berlangsungnya proses belajar yang baik. Begitu pula dengan faktor pergaulan siswa, adanya teman yang baik, sehingga membuat kegiatan belajar menjadi menyenangkan serta penting pula untuk menciptakan keharmonisan hubungan diantara semua personil sekolah. Jika seluruh hal tersebut telah terpenuhi maka kedisiplinan dan tata tertib sekolah dapat ditegakkan secara konsekuen dan konsisten.

\section{Metode Penelitian}

Penelitian ini termasuk jenis penelitian kuantitatif. Yaitu penelitian yang menggunakan perhitungan angka seacra dominan, mulai dari pengumpulan data, penafsiran terhadap data tersebut, serta penampilan, dan hasilnya. Metode analisis data yang digunakan uji normalitas digunakan untuk mengetahui apakah populasi data terdistribusi normal atau tidak sebagai persyaratan 
untuk analisis berikutnya. Normalitas data dapat diketahui melalui beberapa metode diantaranya rasio skewness, rasio kurtosis, uji kolmogorov smirnov, spirowilk, dan plot. Data dinyatakan berdistribusi normal jika signifikansi $(\alpha)$ lebih besar dari 0,05 (kesalahan 5\%). Kurva yang menggambarkan distribusi normal adalah kurva normal yang berbentuk simetris dengan digambarkan penyebaran datanya berada disekitar sumbu diagonal grafik dengan menggunakan plot (normal probability plots).

\section{Hasil Penelitian dan Pembahasan}

Hasil dari pengumpulan data sekunder yang dilakukan dengan menggunakan penyajian data pada penelitian ini menggunakan tabel kontigensi dengan berbantuan software IBM for SPSS versi 23.

\subsection{Analisis Data Penelitian}

\subsubsection{Uji Normalitas}

Berdasarkan hasil uji kolmogorov smirnov diperoleh temuan penelitian bahwa data penelitian ini mempunyai sebaran data yang normal, hal ini diperkuat dengan keofisien asymp.sig. (2-tailed) bernilai $0.385>0.05$, berdasarkan hal tersebut maka uji parametik dapat dilakukan

\subsubsection{Uji Homoginetas}

Berdasarkan uji levene's test didapatkan hasil penelitian yaitu bahwa kelompok data mempunyai variansi yang homogen, yang dijelaskan melalui koefisien sig $=0.061>0.05$. Berdasarkan hal tersebut maka persayaratan uji anova dua arah telah terpenuhi.

\subsection{Hasil Analisis Data}

\subsubsection{Pengaruh Jalur Masuk terhadap Prestasi Belajar Mahasiswa}

Tabel 1 Uji Multiple Comparisons

\begin{tabular}{|c|c|c|c|c|}
\hline \multicolumn{2}{|c|}{ Jalur Masuk } & Taraf Sig & Nilai Sig & Berdistribusi \\
\hline SBMPTN & SNMPTN & 0.89 & 0.05 & Tidak Terdapat Perbedaan \\
\cline { 2 - 5 } & Mandiri & 0.00 & 0.05 & Terdapat Perbedaan \\
\hline SNMPTN & SBMPTN & 0.89 & 0.05 & Tidak Terdapat Perbedaan \\
\cline { 2 - 5 } & Mandlri & 0.00 & 0.05 & Terdapat Perbedaan \\
\hline Mandiri & SNMPTN & 0.00 & 0.05 & Terdapat Perbedaan \\
\cline { 2 - 5 } & SBMPTN & 0.00 & 0.05 & Terdapat Perbedaan \\
\hline
\end{tabular}

Sumber: Hasil analisis, 2020

Berdasarkan uji scheffe, diperoleh hasil penelitian bahwa, tidak ada perbedaan yang signifikan antara prestasi belajar mahasiswa yang diterima melalui jalur masuk SBMPTN dengan jalur masuk SNMPTN. Hal ini diperkuat dengan nilai koefisien sig $=0.089>0.05$, yaitu terdapat perbedaan prestasi yang signifikan antara jalur
SBMPTN dengan jalur masuk mandiri, yang dinyatakan dalam hasil koefisien sig $=0.000<0.05$, serta ada beda yang signifikan Jalur SNMPTN dengan Jalur Mandiri, yang memunculkan hasil koefisien sig $=0.000<0.05$. Sedangkan jalur masuk yang memiliki perbedaan tertinggi adalah jalur masuk mandiri dengan mean difference sebesar 0.1405 .

\subsubsection{Pengaruh Jurusan SMA terhadap Prestasi Belajar Mahasiswa}

Tabel 2 Uji Multiple Comparisons

\begin{tabular}{|c|c|c|c|c|}
\hline \multicolumn{2}{|c|}{ Jalur Masuk } & Taraf Sig & Nilai Sig & Berdistribusi \\
\hline \multirow{2}{*}{ IPA } & IPS & 0.02 & 0.05 & Terdapat Perbedaan \\
\cline { 2 - 5 } & Bahasa & 0.00 & 0.05 & Terdapat Perbedaan \\
\hline \multirow{2}{*}{ IPS } & IPA & 0.02 & 0.05 & Terdapat Perbedaan \\
\cline { 2 - 6 } & Bahasa & 0.04 & 0.05 & Terdapat Perbedaan \\
\hline Bahasa & IPA & 0.00 & 0.05 & Terdapat Perbedaan \\
\cline { 2 - 6 } & IPS & 0.04 & 0.05 & Terdapat Perbedaan \\
\hline
\end{tabular}

Sumber: Hasil analisis, 2020

Berdasarkan uji scheffe, diperoleh temuan penelitian bahwa terdapat perbedaan yang signifikan antara jurusan IPA dan jurusan IPS, yang dibuktikan dengan koefisien sig $=0.002<0.05$, terdapat perbedaan yang signifikan antara jurusan IPA dengan jurusan bahasa, yang dibuktikan dengan koefisien sig $=0.000<0.05$, terdapat beda prestasi antara jurusan IPS dan jurusan bahasa, temuan ini dibuktikan dengan koefisien sig $=0.004$ $<0.05$, sedangkan jurusan SMA yang memiliki perbedaan rata-rata tertinggi adalah jurusan bahasa, dengan mean difference sebesar 0.0388 .

\subsubsection{Pengaruh Jenis Kelamin terhadap Prestasi Belajar Mahasiswa}

Tabel 3 Uji Report

\begin{tabular}{|c|c|c|}
\hline Jenis Kelamin & Rata-rata & Jumlah \\
\hline Laki-laki & 3.2325 & 130 \\
\hline Perempuan & 3.4390 & 145 \\
\hline Total & $\mathbf{3 . 3 4 1 4}$ & $\mathbf{2 7 5}$ \\
\hline
\end{tabular}

Sumber: Hasil analisis, 2020

Berdasarkan nilai rata-rata, diperoleh temuan penelitian bahwa kelompok responden dengan jenis kelamin perempuan memiliki nilai rerata yang paling tinggi (3.43), dibanding dengan kelompok responden dengan jenis kelamin laki-laki (3.23). Hal ini berarti bahwa kelompok responden perempuan memiliki prestasi belajar yang lebih baik dibandingkan responden laki-laki.

\subsection{Temuan Penelitian}

\subsubsection{Pengaruh Jalur Masuk terhadap Prestasi Belajar Mahasiswa}


Berdasarkan pengujian hipotesis dengan menggunakan uji anova dua jalan, diperoleh hasil bahwa ada pengaruh yang signifikan dan simultan jalur masuk terhadap prestasi belajar mahasiswa.

\subsubsection{Pengaruh Jurusan SMA terhadap Prestasi Belajar Mahasiswa}

Berdasarkan pengujian hipotesis dengan menggunakan uji anova dua jalan, diperoleh temuan penelitian bahwa terdapat pengaruh yang signifikan jurusan SMA terhadap prestasi belajar mahasiswa.

\subsubsection{Pengaruh Jenis Kelamin terhadap Prestasi Belajar Mahasiswa}

Berdasarkan pengujian hipotesis dengan menggunakan uji anova dua jalan, diperoleh temuan penelitian, yang menjelaskan bahwa adanya pengaruh yang signifikan dalam hal jenis kelamin terhadap prestasi belajar mahasiswa.

\subsubsection{Pengaruh Asal Daerah terhadap Prestasi Belajar Mahasiswa}

Berdasarkan pengujian hipotesis dengan menggunakan uji anova dua jalan, diperoleh hasil bahwa tidak terdapat pengaruuh yang signifikan asal daerah terhadap prestasi belajar mahasiswa, temuan ini dibuktikan dengan koefisien sig $=0.925>0.05$. Hal ini berarti baik kelompok subjek penelitian yang berasal dari daerah jawa, maupun subjek penelitian yang berasal dari daerah luar jawa, memiliki prestasi belajar mahasiswa yang relatif sama. Melalui hasil tersebut, berarti tempat tinggal tidak menjadi hal yang berpengaruh terhadap prestasi belajar. Tempat tinggal mahasiswa bisa terdiri dari rumah orang tua, tempat kos, ataupun tinggal bersama dengan kerabat jika mahasiswa tersebut berasal dari luar kota. Tempat tinggal dapat memberikan kenyamanan bagi mahasiswa terutama sebagai tempat melepas penat setelah seharian beraktifitas di kampus. Hal ini membuktikan, bahwa tempat tinggal adalah faktor yang penting. Karena kenyamanan dan kelengkapan fasilitas sangat mempengaruhi prestasi belajar. Hal ini menjelaskan pula bahwa mahasiswa yang tinggal berjauhan dari orang tua atau tinggal di kos yang secara tidak langsung berarti tidak ada yang memantau. Sehingga jika tidak terpantau, maka mahasiswa tersebut akan merasa bebas dan kemungkinan tidak memprioritaskan dengan maksimal waktu yang ada untuk belajar. Namun hasil yang tidak signifikan pada penelitian ini bisa juga disebabkan karena perbedaan jumlah yang relatif jauh antara mahasiswa yang berasal dari jawa dan luar jawa. Mahasiswa jawa pada penelitian ini berjumlah 231, sedangkan mahasiswa luar jawa berjumlah 44. Hal ini dapat memberikan hasil olah data yang tidak signifikan.

\section{Kesimpulan}

Berdasarkan pembahasan pada bab sebelumnya maka kesimpulan dalam penelitian ini adalah sebagai berikut:

a) Terdapat pengaruh yang signifikan dan simultan jalur masuk terhadap prestasi belajar mahasiswa, yang kemudian dilanjutkan. Berdasarkan uji scheffe, diperoleh temuan penelitian bahwa tidak terdapat perbedaan yang signifikan antara jalur masuk SBMPTN dengan jalur masuk SNMPTN, terdapat perbedaan yang signifikan antara jalur masuk SBMPTN dengan jalur masuk mandiri, terdapat perbedaan yang signifikan jalur masuk SNMPTN dengan jalur masuk mandiri;

b) Terdapat pengaruh yang signifikan jurusan SMA terehadap prestasi belajar mahasiswa, kemudian dengan uji post hock diperoleh temuan penelitian bahwa terdapat perbedaan yang signifikan antara jurusan IPA dan jurusan IPS, terdapat perbedaan yang signifikan antara jurusan IPA dengan jurusan bahasa, terdapat perbedaan yang signifikan antara jurusan IPS dan jurusan bahasa;

c) Terdapat pengaruh yang signifikan jenis kelamin terehadap prestasi belajar mahasiswa, dengan membandingkan nilai rata-rata, diperoleh temuan penelitian bahwa kelompok responden dengan jenis kelamin perempuan memiliki nilai rata-rata yang paling tinggi (3.43), dibandingkan kelompok responden dengan jenis kelamin laki-laki (3.23); dan

d) Tidak ada pengaruh yang signifikan asal daerah terhadap prestasi belajar mmahasiswa.

\section{Daftar Pustaka}

Arifin, Zainal. (1990). Evaluasi Instruksional. Bandung: Remaja Rosdakarya.

Faridah. (2003). Faktor-faktor yang Mempengaruhi Prestai Belajar dalam Mata Kuliah Akuntansi Keuangan Menengah. Tesis, Universitas Diponegoro, Semarang.

Garkaz, Mansour., Bahman Banimahd., \& Hadis Esmaeili. (2011). Factors Affecting Accounting Students' Performance: The Case Of Students At The Islamic Azad University. Paper dipresentasikan di International Conference on Education and Educational Psychology (ICEEPSY 2011). Istanbul, Turki: EFPA.

Guney, Yilmaz. (2009). Exogenous and endogenous factors impacting student performance in undergraduate accounting modules. Accounting Education, 18(1), 51-73.

Dalyono, M. (2005). Psikologi Pendidikan. Jakarta: Rineka Cipta.

Ika, Desi. (2010). Pengaruh Kecerdasan Emosional dan Spiritual Terhadap Sikap Etis Mahasiswa 
Akuntansi Dipandang dari Segi Gender (Sudi pada Perguruan Tinggi Negeri di Kota Medan). Skripsi, Universitas Sumatera Utara, Medan.

Koh, M.Y., \& Koh, H.C. (1999). The Determinants of performance in an accountancy degree course. Accounting Education: An International Journal, 8(1), 13-29

Nurkholis, Agus. (2007). Faktor-Faktor yang Mempengaruhi Prestasi Belajar Mata Pelajaran Ekonomi Pada Siswa Kelas VIII MTs. Nurussalam Tersono Kabupaten Batang. Skripsi, Fakultas Ekonomi Universitas Negeri Semarang, Semarang.

Nuryoto, Sartini. (1998). Perbedaan Prestasi Akademik antara Laki-laki dan Perempuan Studi di Wilayah Yogyakarta. Jurnal Psikologi, 2, 16- 24.

Setiyoningsih, Titik. (2007). Pengelolaan Pembelajaran IPA Berbasis Lingkungan di SMPN I Gabus Grobogan. Tesis, Universitas Muhammadiyah Surakarta.

Sudjana, Nana. (1987). Dasar-dasar Proses Belajar Mengajar. Bandung: Balai Pustaka.

Widayati ,Tatik. (2005). Pengaruh Motivasi, Dukungan Orang Tua dan Asal Sekolah terhadap Prestasi Belajar Mata Pelajaran Akuntansi pada Siswa Kelas II MA Al-Asror Patemon Gunungpati Semarang Tahun Pelajaran 2004/ 2005. Skripsi, Universitas Negeri Semarang, Semarang.

Winkel, WS. (1991). Psikologi Pengajaran. Jakarta: Gramedia.

Qudratullah, Mohammad Farhan. (2014). Pengaruh Jalur Penerimaan Mahasiswa dan Asal Sekolah terhadap Prestasi Mahasiswa di Fakultas Sains dan Teknologi UIN Sunan Kalijaga Mohammad Farhan Qudratullah. Jurnal Fourier, 3(1), 9-15. 